\title{
Assessment of contaminant concentrations in sediments, fish and mussels sampled from the North Atlantic and European regional seas within the ICON project
}

\author{
Robinson Craig D. ${ }^{1,{ }^{*}}$, Webster Lynda ${ }^{1}$, Martínez-Gómez Concepción ${ }^{2}$, Burgeot Thierry ${ }^{3}$, \\ Gubbins Matthew J. ${ }^{1}$, Thain John E. ${ }^{4}$, Vethaak A. Dick ${ }^{5,6}$, Mcintosh Alistair D. ${ }^{1}$, Hylland Ketil ${ }^{7}$ \\ ${ }_{1}^{1}$ Marine Scotland Science, Marine Laboratory, 375 Victoria Road, Aberdeen, AB11 9DB, UK \\ 2 Instituto Español de Oceanografía (IEO), Oceanographic Centre of Murcia, Varadero 1, P.O. Box 22, \\ 30740 San Pedro del Pinatar, Murcia, Spain \\ ${ }^{3}$ IFREMER, Laboratory of Ecotoxicology, Rue de I'lle d'Yeu. B.P. 21105, F-44311 Nantes, Cédex 03, \\ France \\ ${ }^{4}$ Cefas, Weymouth Laboratory, The Nothe, Barrack Road, Weymouth, Dorset, DT4 8UB, UK \\ ${ }^{5}$ Deltares, Marine and Coastal Systems, P.O. Box 177, $2600 \mathrm{MH}$ Delft, The Netherlands \\ ${ }^{6}$ Institute for Environmental Studies, VU University Amsterdam, De Boelelaan 1087, 1081 HV \\ Amsterdam, The Netherlands \\ ${ }^{7}$ Department of Biosciences, University of Oslo, P.O. Box 1066, Blindern, N-0316 Oslo, Norway \\ * Corresponding author : Craig D. Robinson, Tel.: +44 (0)1224 876544. ; \\ email address : craig.robinson@gov.scot
}

\begin{abstract}
:
Understanding the status of contaminants in the marine environment is a requirement of European Union Directives and the Regional Seas Conventions, so that measures to reduce pollution can be identified and their efficacy assessed. The international ICON workshop (Hylland et al., in this issue) was developed in order to test an integrated approach to assessing both contaminant concentrations and their effects. This paper describes and assesses the concentrations of trace metals, polycyclic aromatic hydrocarbons, and polychlorinated biphenyls in sediments, mussels, and fish collected from estuarine, coastal and offshore waters from Iceland to the Mediterranean Sea. For organic contaminants, concentrations progressively increased from Iceland, to the offshore North Sea, to the coastal seas, and were highest in estuaries. Metals had a more complex distribution, reflecting local anthropogenic inputs, natural sources and hydrological conditions. Use of internationally recognised assessment criteria indicated that at no site were concentrations of all contaminants at background and that concentrations of some contaminants were of significant concern in all areas, except the central North Sea.
\end{abstract}




\section{Graphical abstract}

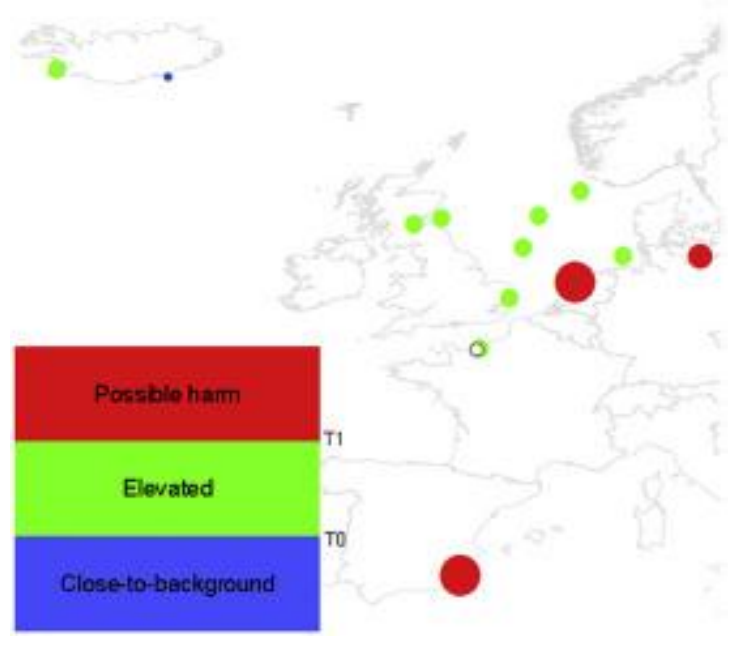

\section{Highlights}

- Sediments, fish and mussels were collected from Iceland to the Mediterranean Sea. Concentrations of organics were lowest at Iceland and highest in the Seine estuary. $\rightarrow$ Concentrations of metals were highest at Cartagena in the Mediterranean Sea. At most sites, concentrations of at least one contaminant were of significant concern.

Keywords : Integrated assessment, ICES, North Atlantic, North Sea, Baltic Sea, Mediterranean Sea, Polycyclic aromatic hydrocarbons (PAHs), Polychlorinated biphenyls (PCBs), Trace metals, Environmental monitoring

\section{Introduction}

The monitoring and assessment of contaminants in European seas has been undertaken for many years to satisfy the requirements of the Regional Seas Conventions (RSCs), i.e. OSPAR for the NE Atlantic (including the North Sea), HELCOM for the Baltic Sea, MED POL for the Mediterranean Sea. From 2014, Descriptor 8 of the European Union Marine Strategy Framework Directive (MSFD; EU, 2008a) requires the monitoring of contaminants within regular assessment cycles and aims to achieve Good Environmental Status for European seas by 2020. States with coasts in more than one Regional Sea (e.g. France, Spain), have an 
operational requirement to harmonise approaches between RSCs and are making use of advice from the International Council for the Exploration of the Sea (ICES) to do this.

OSPAR Contracting Parties are committed to participate in its Coordinated Environmental Monitoring Programme (CEMP), under which a number of contaminants and biological effects are either mandatory, or voluntary determinants. Mandatory CEMP determinants include polycyclic aromatic hydrocarbons (PAHs) in sediment and shellfish, polychlorinated biphenyls (PCBs), polybrominated biphenyl ethers (PBDEs) and hexabromocyclododecane (HBCDD) in sediments, fish liver and shellfish, the toxic metals $\mathrm{Cd}, \mathrm{Hg}$ and $\mathrm{Pb}$ in sediments and biota, and endocrine disruption (imposex) in gastropod molluscs. Voluntary (pre-CEMP) chemical determinants include chlorinated dioxins and furans, alkylated-PAHs, polyfluorinated compounds (PFC)s in sediment and biota, and PFCs in water. Pre-CEMP biological effects determinants include metals-specific effects, $\mathrm{PAH}$-specific effects, and general biological effects (OSPAR, 2010a). Through its regional coordination role under the MSFD, OSPAR has made recommendations regarding the use of common and candidate indicators for monitoring under Descriptor 8 (Concentrations of contaminants are at levels not giving rise to pollution effects). Common indicators include metals, organotins, PAHs, PCBs, and PBDEs in sediments, metals and PCBs in fish, and metals, PAHs and PCBs in mussels; candidate indicators include biological effects, i.e. lysosomal membrane stability, external fish disease, cytochrome P450 (EROD) activity and biliary PAH metabolite concentrations (OSPAR, 2013). The current advice from the International Council for the Exploration of the Seas (ICES) is that the monitoring and assessment of environmental contaminants are fully integrated, with both contaminant concentrations and their biological effects being monitored, reported, and assessed in a coherent manner (Davies and Vethaak, 2012; Vethaak et al., this issue). In the North Atlantic, OSPAR has developed criteria (background assessment concentrations (BACs) and environmental assessment concentrations, EACs) to assess the significance of observed contaminant concentrations (OSPAR, 2009), although under the MSFD European Environmental Quality Standards (EQSs) should be used where they are available (e.g. for some contaminants in biota). Similarly, regionally-specific assessment criteria are available for use in the Mediterranean (UNEP/MAP, 2011; Angelidis et al., 2011; Benedicto et al., 2012; see also Martínez-Gómez et al., this issue). During the ICES advice drafting stage, a multipartner project to examine the integrated approach to environmental assessment at the regional seas level was conducted (International Workshop on Integrated Assessment of Contaminant Impacts on the North Sea, ICON; Hylland et al., this issue). Our paper describes and assesses the contaminant concentrations of sediment and biota samples collected from Iceland, the North Sea, the Baltic Sea, and the Mediterranean Sea during the ICON project. The exposure of ICON fish samples to PAHs is assessed in an accompanying paper on bile metabolites (Kammann et al., this issue).

\section{Material and methods}

2.1. Sample collection

Samples were collected by shoreline sampling (mussels; 2008-2011), or from research cruises (fish, sediments) conducted in 2008 and 2009 by the participating 
laboratories utilising the research vessels Scotia, Alba na Mara (both Marine Scotland, UK), Walter Herwig III (Thünen-Institut für Fischereiökologie, Germany), Francisco de Paula Navarro (Instituto Español de Oceanografía (IEO), Spain) and Gwendrez (Ifremer, France). Fish and sediments from the Wadden Sea were collected from a small boat, with surface sediments collected by van Veen grab and flounder collected using a $3 \mathrm{~m}$ beam trawl. Mussels were hand collected between September and February and not during the spawning period in order that the animals had normal condition and lipid level. All sampling was in accordance with OSPAR guidelines (OSPAR, 1999). After collection, samples for chemical analysis were stored frozen $\left(-20^{\circ} \mathrm{C}\right)$ and dispatched on dry i ce to Marine Scotland Science (MSS), Aberdeen, UK. Sampling site details are in Table 1 and locations are shown in Figure 1. Occasional samples were lost or were found unsuitable for analysis; in such cases alternative data (from the same year) were obtained from national monitoring programs when they were available. To present and assess national data consistently with ICON data, a conversion factor of 5 was used to convert between mussel dry weight and wet weight where the moisture content was not available.

The upper $2 \mathrm{~cm}$ of sediment were collected (e.g. by Day or van Veen grab), thoroughly mixed and then frozen at $-20^{\circ} \mathrm{C}$ as separ ate aliquots for the determination of organic and inorganic compounds. Fish were collected by bottom or beam trawls, examined for external disease and dissected at sea for tissue sampling. Otoliths were removed and each fish subsequently aged by sclerochronology, except red mullet which were in the size range $12-18 \mathrm{~cm}$ and age was estimated as being Class I-III using specific size-age models (Kinacigil et al., 2001; Martínez-Gómez et al., this issue). In order to provide sufficient material for the chemical analyses, liver samples were pooled (5 pools of 5 same-sex fish per site for metals), minced and thoroughly mixed before being divided into aliquots for organic or metals analyses and frozen at $-20^{\circ} \mathrm{C}$; flesh samples were treated similarly, though for metals analysis only. After being defrosted and drained of liquor, mussel soft tissues were removed from the shells, pooled, homogenised using an ultra-Turrex homogeniser (VWR, Leicestershire, UK) and separate aliquots frozen for subsequent determinations of trace metals or organic contaminants. For PCB analyses, the 5 fish liver pools from each site were further combined according to their sex and homogenised such that two determinations of liver PCB concentrations were undertaken per site and species. Analysis of contaminants in red mullet was conducted in muscle fish tissue, following guidelines of the MED POL programme (UNEP/FAO/IOC/IAEA, 1993).

At most sites the collected mussels were from natural populations, although those from the sampling sites at Cape Palos and Cartagena (SE Spain), had been transplanted there (for 6 weeks) from a reference site located in open waters near Malaga, SE Spain (see Martínez-Gómez et al., this issue). From each mussel sampling site, at least 20 individuals of a given size range (usually $45 \pm 10 \mathrm{~mm}$ ) were hand collected from below the water surface, close to the low water mark, and transported cool prior to frozen storage.

At all stages, appropriate care was taken to avoid adventitious contamination of the sample and losses of analytes, including the use of acid-washed non-metallic tools and containers when handling samples for metals analyses and the use of solvent- 
176

177

178

179

180

181

182

183

184

185

186

187

188

189

190

191

192

193

194

195

196

197

198

199

200

201

202

203

204

205

206

207

208

209

210

211

212

213

214

215

216

217

218

219

220

221

222

223

224

225 washed metallic or glass materials when handling samples for the determination of organic contaminants.

\subsection{Trace metals analyses}

2.2.1. Sample digestion

Sediment samples were freeze-dried, passed through a $2 \mathrm{~mm}$ sieve, ground with a pestle and mortar, and digested using a Multiwave 3000 Microwave Digestion System (Anton Paar, St Albans, UK). Approximately $250 \mathrm{mg}$ ( $\pm 50 \mathrm{mg}$ ) of powdered sediment was digested using $2 \mathrm{~mL}$ of hydrogen peroxide, $1.5 \mathrm{~mL}$ of hydrofluoric and $5 \mathrm{~mL}$ of nitric acid (VWR Merck, Lutterworth, UK); the digestion programme was 15 mins ramp to $200^{\circ} \mathrm{C}$, hold for 25 mins and cool for 30 mins; excess HF was complexed with $10 \mathrm{~mL}$ of saturated boric acid and microwave heating. Homogenised biota samples were also digested using the Multiwave 3000; either $600 \pm 100 \mathrm{mg}$ (wet fish flesh), $450 \pm 50 \mathrm{mg}$ (wet liver, wet mussels), or $250 \pm 50 \mathrm{mg}$ (dried Certified Reference Material, CRM) were digested using $2.5 \mathrm{~mL}$ nitric acid and $3.5 \mathrm{~mL}$ hydrogen peroxide, and a digestion programme of ramp to $70^{\circ} \mathrm{C}$ in 2 minutes, hold for 5 mins, ramp to $200^{\circ} \mathrm{C}$ in 13 mins, hold for 25 minutes and cool for 30 mins. Each digestion run included one Certified Reference Material (CRM) and one procedural blank; after digestion, each sample was diluted to $25 \mathrm{~mL}$ using ultrapure water (>18 M .cm; Elga, Marlow, UK). The following CRMs (NRCC, Canada) were analysed: MESS-3 marine sediment, TORT-2 shellfish hepatopancreas, DORM-3 fish muscle and DOLT-3 fish liver.

\subsubsection{Metals analysis}

The digests were further diluted (20-fold for sediments, 5 -fold for biota) with $1 \%$ nitric acid containing internal standards (Rh, Ir, Sc, Ge, Bi), Au and 1\% thiourea. Au and thiourea (biota only) were used to reduce memory effects in the determination of $\mathrm{Hg}$. Concentrations of trace elements ( $\mathrm{As}, \mathrm{Cu}, \mathrm{Zn}, \mathrm{Cd}, \mathrm{Hg}, \mathrm{Pb}$ ) were determined using matrix-matched calibration standards and an Elan 6100DRC+ inductively coupled plasma mass spectrometer (ICPMS; Perkin Elmer, Buckinghamshire, UK) equipped with a cross-flow nebuliser and Scott spray chamber. Additional elements determined included $\mathrm{Fe}$ and $\mathrm{Al}$ (sediments) and Se (biota). Tuning solutions and analytical standards were obtained from Spex CertiPrep, Stanmore, Middlesex, UK.

\subsection{Organic contaminants}

2.3.1. Polychlorinated biphenyls

PCBs were determined according to Webster et al. (2011). Briefly, 10-20 g of dried sediment or $0.5-2 \mathrm{~g}$ of wet tissue were extracted with iso-hexane using pressurised liquid extraction (Dionex Ltd., Camberley, Surrey, UK,) and deactivated silica cleanup. Concentrations of 32 PCB congeners (including the "ICES-7" indicator PCBs, CBs 28, 52, 101, 118, 138, 153 and 180) were determined by gas chromatography with electron capture detection (GC-ECD). When summing congener concentrations, zero was used in place of values below the detection limit (LoD), and a value of half the limit of quantification (LoQ) was used when trace concentrations were too low to be quantified.

\subsubsection{Polycyclic aromatic hydrocarbons}

PAHs were determined in sediment and mussels according to Webster et al. (2009 and 2011). Briefly, deuterated internal standards were added to approximately $20 \mathrm{~g}$ 
of wet sediment which was then sonicated in $40 \mathrm{~mL}$ dichloromethane/methanol (1:1 $\mathrm{v} / \mathrm{v})$ for 5 mins and centrifuged to remove the solids. The supernatant was liquidliquid extracted and dried with sodium sulphate. The extraction was repeated, the extracts were combined, solvent exchanged into iso-hexane and concentrated by rotary evaporation. The aliphatic and aromatic fractions were separated by isocratic high performance liquid chromatography (HPLC) and the aromatic fraction further concentrated (to approx. $300 \mu \mathrm{L}$ ) before the concentrations of 40 parent and alkylated PAHs were determined by gas chromatography and mass spectrometry (GCMS) in selective ion monitoring mode. Mussels (approx. $10 \mathrm{~g}$ wet wt) were extracted by saponification with methanol and sodium hydroxide in water for 4 hours and extracted with iso-hexane/methanol/water $(4: 1: 1)$. The extracts were concentrated, purified and analysed as for sediments.

\subsection{Supporting determinants}

The proportions of fine grained material $(\%<63 \mu \mathrm{m}$ and $\%<20 \mu \mathrm{m})$ in freeze-dried sediments initially sieved to $<2 \mathrm{~mm}$ were determined by laser granulometry (Mastersizer 2000; Malvern Instruments, Worcestershire, UK) and the total organic carbon (TOC) content was determined using a ThermoQuest FlashEA 1112 elemental analyser (Thermo Scientific, Hemel Hempstead, UK) following acidification of the sediment with $15 \%$ hydrochloric acid to remove inorganic carbonate.

\subsection{Quality Control}

Analyses at MSS were conducted within a laboratory accredited to ISO-17025 by the UK Accreditation Service (UKAS) for the determinations of metals, PCBs, PAHs, particle size and TOC in marine sediment and/or biota. All analytical batches included the analysis of Certified or Laboratory Reference Materials (LRMs), with the results recorded on Shewart control charts with warning and control limits set at twoand three-times standard deviation respectively. External quality assurance was confirmed through successful participation in the QUASIMEME proficiency testing scheme.

\subsection{Data analysis and assessment}

All statistical analyses were performed using Minitab v16. Patterns of contaminant concentration and composition were investigated using principle components analysis (PCA). Where sufficient data were available (e.g. metals in fish liver), oneway ANOVA and Tukey's post hoc tests were conducted on data (log-transformed where required) from fish of the same species in order to investigate between-site differences in concentration; non-parametric data were analysed by the KruskallWallis ANOVA by ranks and Dunn's post hoc test (Orlich, 2000) using a macro available from http://support.minitab.com.

To assess the significance of determined contaminant concentrations, data were compared with internationally recognised assessment criteria (Table 2) and presented using a "traffic light" system, where blue indicated concentrations at background, green indicated elevated concentrations and red indicated unacceptably high concentrations (Fig. 2). The assessment followed the OSPAR approach (2008) using Background Assessment Concentrations (BACs) for the blue/green transition $\left(T_{0}\right)$ and Environmental Assessment Criteria (EACs) for the green/red $\left(T_{1}\right)$ transition, with missing EACs being replaced by using other established criteria such as US Sediment Quality Guidelines (Effects Range Low, ERLs; NOAA, 1999) or the 
Maximum Permitted Concentrations (MPCs) under EU food regulations

277 (EC/1881/2006, as amended). OSPAR BACs/EACs for sediment are normalised to $2785 \% \mathrm{Al}$ (metals) or 2.5\% organic carbon (organic contaminants), whilst ERLs are for 279 bulk sediment concentrations; we compared normalised or non-normalised sediment concentrations as appropriate for the definition of the respective assessment criteria. For the Mediterranean, MED POL has developed BACs for some contaminants (e.g. metals in sediments; UNEP/MAP, 2011) whilst Spain has developed others for use in biota for its Mediterranean waters (Benedicto et al., 2011). MED POL has not yet developed EACs for its region, but suggests using the OSPAR approach (i.e. using OSPAR EACs, ERLs, or MPCs; UNEP/MAP, 2011). To date, neither OSPAR nor MED POL intend to use EU Environmental Quality Standards (EQSs) for the green/red transition $\left(T_{1}\right)$ in biota (e.g. for $\mathrm{Hg}$, fluoranthene, benzo[a]pyrene). In this paper we have used the biota EQSs for $\mathrm{Hg}$, fluoranthene and benzo[a]pyrene as they are legal standards intended to protect the ecosystems of saline waters.

289

290

291

292

293

294

295

296

297

298

299

300

301

302

303

304

305

306

307

Mean concentrations and their 95\% confidence intervals were compared with the Assessment Criteria (OSPAR, 2008); where statistical confidence intervals were not available, the analytical result and its uncertainty were compared to the Assessment Criteria. In order to avoid being overly protective, individual organic contaminants were assessed against their respective assessment criteria and two or more PAH compounds or PCB congeners had to exceed a transition threshold before the site was assessed as having exceeded that threshold, so for a site to be "red" for PAHs in sediment, concentrations of at least two PAH compounds had to exceed their individual $E R L$ values.

\section{Results and Discussion}

\subsection{Trace metals}

A plot of the first two Principle Components from a PCA of sediment metal concentrations (Fig. 3) grouped the five offshore sites (Egersund Bank, Ekofisk, offshore Firth of Forth, Dogger Bank and German Bight) and the Alde estuary closely together (with low metal concentrations), whilst the Wadden Sea and, especially, 308 Cartagena separated due to higher metal concentrations; the former is likely due to 309 inputs from the River Rhine (Bakker et al., 2009), whilst mining wastes and $\mathrm{Hg}$ biogeochemical cycling probably account for the higher metals concentrations in SE Spain (Benedicto et al., 2008, 2011; Cossa and Coquery, 2005). The Blackness, Baltic Sea and Seine estuary sites formed a separate group with moderate responses on both the first (PC1) and second (PC2) principle components, whilst the SE Iceland (IS1) site was further separated on PC2 (relatively high for $\mathrm{Cu}$ and low for As and $\mathrm{Pb}$ ). As well as in sediments (Table S1; Figs. S1-S3), concentrations of $\mathrm{Hg}$, $\mathrm{Zn}, \mathrm{Cd}$ and $\mathrm{Pb}$ were high in biota from Cartagena compared to the other sites (Tables S4 and S5; Fig.s S4-S6), which is consistent with previous reports that the area is one of the most heavily metal polluted areas of the western Mediterranean Sea, due to marine dispersal of mining waste from the nearby Portmán bay area (Benedicto et al., 2008, 2011). Markedly high concentrations of $\mathrm{Zn}, \mathrm{Pb}, \mathrm{Hg}$ and $\mathrm{Cd}$ have been reported in sediment and/or biota (Benedicto et al., 2005, 2008, 2011), as well as an acute toxicity to invertebrates exposed to sediments from this area (Cesar et al., 2004). Sublethal contaminant-related effects have been described in mussels and red mullet from the surroundings of Cartagena marine area (Martínez-Gómez et al., 2008, 2012, this issue; Fernández et al., 2010, 2011). 
Sediment cadmium concentrations (Tables S1-S3) did not exceed the ERL at any site, and were close-to-background in the Alde estuary (SE England) and in the central North Sea (Fig. S1.). In contrast to sediments, Cd concentrations tended to be higher in livers of dab from deeper, offshore, sites than from inshore areas (Table S5; Fig. S4 \& S5), but were also high at SE Iceland (IS1; $905 \mu \mathrm{g} / \mathrm{kg}$ ) and SW Iceland (IS2; $514 \mu \mathrm{g} / \mathrm{kg}$ ). The differences in Cd concentrations were not related to age as fish from Ekofisk, offshore Firth of Forth, Dogger Bank, German Bight and the Baltic Sea sites were all approximately 2.5 years old, but had contrasting liver Cd concentrations (approx. $1300 \mu \mathrm{g} / \mathrm{kg} \mathrm{w.w} \mathrm{at} \mathrm{Ekofisk,} \mathrm{approx.} 600 \mu \mathrm{g} / \mathrm{kg} \mathrm{w} . \mathrm{w}$. at the offshore locations Firth of Forth and Dogger Bank, in contrast to ca. $150 \mu \mathrm{g} / \mathrm{kg} \mathrm{w.w}$ at the German Bight and the Baltic Sea sites). Flounder were only collected from inshore and estuarine waters. In liver, $\mathrm{Cd}$ concentrations were highest at the Parfond site in the Seine (ANOVA, p<0.001). High Cd concentrations in mussels from the Seine estuary have also been reported previously (Chiffoleau et al., 2001) and ascribed to local inputs of phosphogypsum, a calcium sulphate that is a byproduct of phosphoric acid and naturally enriched with $\mathrm{Cd}$. In mussels, Cd concentrations were highest from the Icelandic sites and lowest in the Seine and Wadden Sea (Table S4). In summary, Cd concentrations were high in sediment, fish and mussels from both Iceland and Cartagena, low in sediment and biota from the Forth; offshore, fish (dab) had elevated $\mathrm{Cd}$ concentrations whilst corresponding sediment concentrations were low. Higher concentrations of $\mathrm{Cd}$ have previously been reported in cod from Iceland compared to other areas of the North Atlantic (Sturludottir et al., 2014). As Cd has a nutrient-like behaviour, the differences in Cd concentrations in different parts of the region may reflect differences in hydrographic conditions (Yeats, 1988), as well as possible volcanic inputs in Iceland and mining wastes in SE Spain.

For all matrices, concentrations of $\mathrm{Pb}$ (Tables S1-S5; Figs. 3, S2, S4-S6) were highest at Cartagena, exceeding the sediment ERL and the EC food Regulation limit for mussels. As noted above, Cartagena is known to have a high background due to natural geology, and to be contaminated with metals from mining activities. Concentrations of $\mathrm{Pb}$ in fish (Table S5; Fig.s S4 and S5) and mussels (Table S4; Fig. S6) from the Forth estuary (Blackness and Alloa sites) were also high compared to other sites, whilst surface sediment concentrations were similar to elsewhere (Fig. $\mathrm{S2}$ ); this could indicate greater bioavailability of sediment-associated $\mathrm{Pb}$ in the Forth, or possibly greater availability from other sources, such as the water column, here than elsewhere. As well as high $\mathrm{Pb}$, flounder from Blackness also had the highest liver $\mathrm{Cu}$ and $\mathrm{Zn}$ concentrations (Fig. S4 and S5; Table S5; ANOVA, $p<0.001$ for both elements). Increased tissue concentrations of essential metals such as $\mathrm{Cu}$ and $\mathrm{Zn}$ may be caused by exposure to the metals themselves, but could also be modulated by other stressors. The inner Firth of Forth and the Forth estuary have had over 200 years of industrial and domestic inputs (Smout and Stewart, 2012) and the sedimentary reservoir of historic pollutants is therefore significant, particularly in the estuary (Baxter et al., 2011). Elsewhere, sediment Pb concentrations (Fig. S2) were above the ERL at the Dutch Wadden Sea site and the Baltic Sea (Mecklenberg Bight) site, whilst being lowest at the Icelandic sites (1.7-1.9 $\mu \mathrm{g} / \mathrm{kg}$ ), although only the SE Iceland (IS1) site was assessed as at background for $\mathrm{Pb}$ in sediment. Patterns of $\mathrm{Pb}$ concentrations in dab liver were similar to those of $\mathrm{Cd}$, with highest values in the central North Sea (especially Ekofisk); however, unlike Cd, 
concentrations of $\mathrm{Pb}$ were low in both sediment and fish liver (both dab and haddock) from Iceland (Tables S1-S5; Figs. S2, S4 and S5).

378

379

380

381

382

383

384

385

386

387

388

389

390

391

392

393

394

395

396

397

398

399

400

401

402

403

404

405

406

407

408

409

410

411

412

413

414

415

416

417

418

419

420

421

422

423

424

425

High $\mathrm{Hg}$ concentrations in sediments, fish and mussels (Tables S1-S5; Fig.s 3, S3S6) were found at Cartagena, where $\mathrm{Hg}$ exceeded the ERL for sediments and the EQS for biota (although not the EC food Regulation limits). Due to underlying geology, much of the Mediterranean Sea has high background levels of $\mathrm{Hg}$ (Bernhard, 1988; Martinez-Frias et al., 1998), although the reasons for high biota $\mathrm{Hg}$ concentrations in Mediterranean species may also be due to biochemical or ecological factors (Cossa and Coquery, 2005; Cresson et al., 2014). Elsewhere, $\mathrm{Hg}$ concentrations exceeded the sediment ERL at most coastal and estuarine sites, and were above background everywhere except the Alde estuary, SE Iceland (IS1) and the central North Sea (Fig. S3). Similarly to $\mathrm{Cd}$ and $\mathrm{Pb}$, higher $\mathrm{Hg}$ concentrations were found in dab from the central North Sea (where sediment concentrations were low) than in dab from Iceland, the Baltic, or the southern North Sea. With respect to $\mathrm{Hg}$, under European Union Directives, the quality of estuarine, coastal, territorial (Water Framework Directive; WFD) and offshore waters (Marine Strategy Framework Directive; MSFD) in Europe should be assessed using the EQS. This is a legal standard, set for biota and intended to protect against secondary poisoning due to trophic magnification (EC, 2005). Biota $\mathrm{Hg}$ concentrations at all sites (except mussels from Hvassahraun and Cape Palos) exceeded the EQS (20 $\mathrm{g} \mathrm{kg}^{-1}$ w.w.). The Hg EQS was derived from toxicological data according to the EQS Technical Guidance Document (EC, 2011), but its use presents difficulties as it is set at a level $(20 \mu \mathrm{g} / \mathrm{kg}$ w.w.) which is close to or below the natural background of both the OSPAR region (BAC $=18$ or $35 \mu \mathrm{g} / \mathrm{kg}$ w.w. for mussels or fish muscle respectively; OSPAR, 2009) and the Spanish Mediterranean (40 or $120 \mu \mathrm{g} / \mathrm{kg} \mathrm{w} . \mathrm{w}$. for mussels or fish muscle respectively; Benedicto et al., 2012). Furthermore, the latest EC guidance on the implementation of the biota EQSs states that the EQS is set for animals of Trophic Level 4 and that concentration data should be corrected using trophic magnification factors before comparison with it (EU, 2014). In effect, this reduces the EQS to approximately $4 \mu \mathrm{g} / \mathrm{kg} \mathrm{w} . \mathrm{w}$. for mussels or approximately 11 $\mu \mathrm{g} / \mathrm{kg}$ w.w. for flounder. These values are well below the OSPAR BAC and not attained anywhere in this study, even in relatively remote sites such as Iceland. An important discussion needs to be had around why the toxicological EQS is below background, and of any legal implications for Member States arising from the high frequency of samples/sites exceeding the EQS, but this is beyond the scope of this paper.

\subsection{PCBs}

PCB concentrations were determined for 8 (of 14) sediment stations. Three locations (Blackness, Cartagena and Wadden Sea) were assessed as above background (Fig. S7) as they had two or more congeners exceeding their respective BACs, but no sites were assessed as red ( $\geq 2$ congeners above the EAC). At only Bjarnarhöfn were PCB concentrations in mussels (Table S4) at background (blue), whilst two sites were assessed as red for PCBs in mussels: 2 congeners exceeded EACs at Blackness and 5 congeners did so in mussels from Le Havre in the Seine, where PCB concentrations also exceeded the EC food regulation limit. Dab from the Seine estuary at Parfond also had extremely high liver PCB concentrations $\left(\sum \mathrm{PCB}_{\text {ICES-7 }}=1668 \mu \mathrm{g} \mathrm{kg}{ }^{-1}\right.$ w.w.; Table S5b), and this was the only site to be 
assessed as red for PCBs in liver as the concentrations exceeded the EC food regulation limit (fish liver EACs were not used due to a lack of lipid data for normalisation). Our findings of biota PCB concentrations an order of magnitude higher in the Seine than elsewhere is consistent with the Seine Bay and Seine estuary having previously been reported as amongst the most PCB contaminated areas in Europe (Cachot et al., 2006; Bodin et al., 2008). At the other ICON sites, the $\Sigma P C B_{\text {ICES-7 }}$ concentrations in fish livers were in the range $10-100 \mu \mathrm{g} \mathrm{kg}^{-1} \mathrm{w}$.w. (Table S4b), which is consistent with reported concentrations in plaice liver from the north-western North Sea (Webster et al., 2011). As with sediments, lowest PCB concentrations in dab liver were recorded at the central North Sea (Egersund Bank, Ekofisk and Dogger Bank; $19-24 \mathrm{\mu g} \mathrm{kg}^{-1}$ w.w.), with relatively high concentrations at the more inshore Baltic Sea and German Bight sites (96-117 $\mu \mathrm{g} \mathrm{kg}^{-1}$ w.w.). Whilst absolute sediment PCB concentrations were similar in the German Bight to elsewhere, TOC-normalised sediment concentrations were relatively high (Tables S1 and S2). This probably reflects the transport of fine particles from the River Elbe to the area, whilst the relatively high dab liver concentrations indicate that the sediment PCBs at this site are bioavailable. The River Elbe is a source of contaminants to the North Sea and a pollution gradient from it to the German Bight is well known (Schwarzbauer et al., 2000; Umlauf et al., 2011).

\subsection{PAHs}

Concentrations of PAHs in sediment (sum of 11 compounds; Fig. 4, Table S1) were extremely variable, ranging from $<1 \mu \mathrm{g} / \mathrm{kg}$ d.w. at SE Iceland (IS1), to almost 2,000 $\mu \mathrm{g} / \mathrm{kg} \mathrm{d.w}$. at Blackness in the Forth estuary. After normalisation to $2.5 \% \mathrm{TOC}$ content, concentrations at most sites were in the range 300-350 $\mu \mathrm{g} / \mathrm{kg}$ d.w. (Table S2), being slightly lower at Cartagena $(182 \mu \mathrm{g} / \mathrm{kg} \mathrm{d.w}$.) and higher at the Seine (539 $\mu \mathrm{g} / \mathrm{kg}$ d.w.). Iceland still had very low concentrations $(\sim 20 \mu \mathrm{g} / \mathrm{kg}$ d.w.) whilst the Baltic Sea $(805 \mu \mathrm{g} / \mathrm{kg}$ d.w.) and Blackness sites $(2669 \mu \mathrm{g} / \mathrm{kg}$ d.w.) had high TOCnormalised PAH concentrations. The SE Iceland (IS1), Ekofisk and Egersund Bank sites were assessed as close-to-background for sediment PAHs (<2 compounds above BAC) and all the other sites, except Blackness, were assessed as green; at Blackness all of the PAH compounds were above background in sediment, with phenanthrene and anthracene being above their respective ERLs. Relatively high $\mathrm{PAH}$ exposure of mussels was also observed for Blackness compared to the other sites (Table S4), although no PAH exceeded its EAC or EQS. This site is located in the Forth estuary of eastern Scotland, an area that hosts a large oil refinery and petrochemical complex, together with a large coal-fuelled power station and that has been the site of intense industrial activity for over 250 years (Smout and Stewart, 2012). Similar to previous studies (Rocher et al., 2006), high PAH exposure of biota was also observed in this study for mussels at Le Havre (Seine estuary) compared to Le Moulard (Channel coast; Table S4) and for fish at Parfond in the Seine Bay (Kammann et al., this issue), whilst sediment PAH concentrations were also relatively high $(173 \mu \mathrm{g} / \mathrm{kg} \mathrm{d.w}$.) in the Seine estuary. PAH concentrations for the Seine in this study were comparable to those of earlier studies. Summing the same compounds (phenanthrene, anthracene, fluoranthene, pyrene, benz[a]anthracene, chrysene / triphenylene, benzo[a]pyrene, benzoperylene, indenopyrene) and converting using a wet/dry weight factor of 5 , Rocher et al. (2006) reported mussel concentrations of 60 and $2.5 \mu \mathrm{g} / \mathrm{kg}$ w.w. for Le Havre and Le Moulard, whilst here we 
report 29 and $10 \mu \mathrm{g} / \mathrm{kg}$ w.w. For the same PAH compounds in sediments as reported here, Cachot et al. (2006) reported higher concentrations in the Seine estuary $(1,500-4,000 \mu \mathrm{g} / \mathrm{kg} \mathrm{d}$.w.) than we do here $(173 \mu \mathrm{g} / \mathrm{kg} \mathrm{d.w.})$, but a similar total concentration for Seine Bay sediments $(22.5 \mu \mathrm{g} / \mathrm{kg}$ d.w., compared to $39 \mu \mathrm{g} / \mathrm{kg}$ d.w. in this study). High concentrations of PCBs and PAHs in the Seine can be ascribed to a long history of industrial/urban inputs and high atmospheric deposition in the catchment (see also Burgeot et al., this issue).

Sediment PAH composition profiles (each PAH as a percentage of the total concentration) were investigated by PCA, both with and without the inclusion of naphthalene (Figs. S8 and S9) as no naphthalene data were available for several sites. In both PCAs, the first two PCs explained $82 \%$ of the variation. Coastal North Sea sites (Blackness, Seine estuary, Wadden Sea) separated due to their higher proportions of lighter PAHs, whereas the Baltic Sea, Ekofisk and Egersund Bank sites had progressively greater proportions of heavy PAHs (indenopyrene, benzoperylene and benzofluoranthenes), indicating differing sources of contamination.

The sources of PAH contamination can be identified by the concentration-ratios of parent compounds or of alkylated-to parent PAH ratios and the use of parent PAH concentration-ratios was recently reviewed by Tobiszewski and Namieśnik (2012). However, they also caution that environmental factors can influence the behaviour of individual PAH compounds and thus recommend that more than one ratio should be considered in identifying the likely source of PAH contamination. Using the diagnostic anthracene/(anthracene+phenanthrene) ratio (ANT/[ANT+PHEN]) of Pies et al. (2008; Table 3) the sediment PAHs in this study would appear to be primarily of pyrolytic origin, except at Parfond (Table 4). The use of the fluoranthene/(fluoranthene+pyrene) ratio (FLUT/(FLUT+PYR); Yunker et al., 2002) suggests that this is mostly due to the combustion of coal and biomass (ratio $>0.5$ ), which is generally supported by the use of the indenopyrene/(indenopyrene+benzoperylene) ratio (IcdP/[IcdP+BghiP])which is also $>0.5$ for most sites, with 0.5 being the ratio distinguishing between petroleum combustion (ratio of 0.2-0.5) and coal or biomass (ratio of $>0.5$; Yunker et al., 2002). The ANT/(ANT+PHEN) ratio of sediments from Parfond indicates a petrogenic source, although the anthracene concentration was below the detection limits (LoD/2 used), and this is not in agreement with the FLUT/(FLUT+PYR) ratio, which indicates a fossil fuel combustion source; benzoperylene was not determined here. Tobiszewski and Namieśnik (2012) indicate that anthracene is one of the PAH compounds more subject to environmental variation and that the ANT/(ANT+PHEN) ratio should not be relied upon for accurate source-apportionment without additional evidence (e.g. ratios measured for known local sources, or other diagnostic ratios in agreement), whereas the FLUT/(FLUT+PYR) ratio is more conservative and thus it seems likely that the source of PAH to Parfond is also pyrolysis of fossil fuels. Sediment PAH at the Blackness site appears to have a petroleum or crude oil combustion source, with FLUT/(FLUT+PYR) and IcdP/(IcdP+BghiP) ratios of 0.45, whilst the ratios do not agree on the source of PAHs at Cartagena or the offshore Firth of Forth.

\subsection{Overall assessment}


In the North Sea, the data generally show an increasing gradient of contamination from North to South and from inshore to offshore, which is consistent with other reports (e.g. Salomons et al., 1988; OSPAR, 2010b) and reflects factors such as the higher coastal population density and greater industrial activity. Contaminant concentrations were generally highest in estuaries (e.g. the Seine, Blackness, the Wadden Sea), at Cartagena in SE Spain (especially metals), and at the Baltic Sea site in the Mecklenberg Bight, whilst being low at the offshore sites and in the Alde estuary of eastern England (Tables 2-4, S2-3). Similarly, the Mecklenberg Bight was found to be of moderate or poor status ("disturbed by hazardous substances") in the most recent HELCOM assessment of hazardous substances (HELCOM, 2010).

The Icelandic sites stand out has having high concentrations of some metals, particularly $\mathrm{Cu}$ and $\mathrm{Cd}$, but low concentrations of organic contaminants such as PCBs and PAHs. Iceland is thought to have low inputs of anthropogenic origin (e.g. Skarphedinsdottir et al., 2010; Kammann et al., this issue) and elevated Cu and Cd concentrations in sediments may reflect a higher degree of mineralisation from volcanic inputs. Higher concentrations of $\mathrm{Cd}$ have also been reported in cod from Iceland than from other areas of the North Atlantic (Sturludottir et al., 2014). Higher concentrations of $\mathrm{Cd}$ were also observed in fish from offshore than from inshore areas. Furthermore, fish from Ekofisk, offshore Firth of Forth, Dogger Bank, German Bight and the Baltic Sea sites were all approximately 2.5 years old, but had contrasting liver $\mathrm{Cd}$ concentrations (generalised as higher in the North and lower in the South). As $\mathrm{Cd}$ has a nutrient-like behaviour, the differences in $\mathrm{Cd}$ concentrations may reflect differences in hydrographic conditions (Yeats, 1988). The Mediterranean is known to have high mercury levels (Cossa and Coquery, 2005), whilst the Cartagena area in particular has been subject to historic inputs of metals from mining (Benedicto et al., 2008; 2011) and our findings indicate that sediments and biota (mussels) are still highly contaminated, although direct mining waste inputs ceased in 1990. Concentrations of contaminants were determined in liver from three fish species (dab, flounder and haddock) in northern Europe. Although there was no simple geographical pattern of trace metal concentrations in fish livers, PCB concentrations tended to be highest in livers of fish from the southern North Sea, being particularly high in the Seine Bay and estuary, an area long recognised as being contaminated by PCBs (e.g. Abarnou et al., 1987; Cachot et al., 2006).

The number and proportion of determinant/matrix combinations assessed in each category for each site are shown in Figure 5. In total, there were 211 possible observations; of these, no data were obtained for $15 \%$ of contaminant/matrix combinations (in general this was due to loss of samples/sub-samples), $12 \%$ were at background (i.e. $<T_{0}$ ), $14 \%$ were above the upper $\left(T_{1}\right)$ transition threshold and $44 \%$ were between $T_{0}$ and $T_{1}$. More than $15 \%$ of possible observations were above the $\mathrm{T}_{1}$ transition at the Blackness, Baltic Sea, Wadden Sea, Seine estuary, Le Havre and Cartagena sites.

The most recent major assessment of contaminants and the environmental status of the North Sea was the OSPAR Quality Status Report (QSR2010; OSPAR, 2010b), which assessed the status and trends of $\mathrm{Cd}, \mathrm{Hg}, \mathrm{Pb}, \mathrm{PAH}$ and $\mathrm{PCB}$ concentrations in sediment and biota for the period 2003-2007. Assessments of North Sea concentrations in this study are generally consistent with those of the QSR2010. For some contaminants (e.g. Cd, Pb), concentrations were assessed as of better status 
in this study than in QSR2010. Assessment of PAH status was similar in this study to in the QSR2010. The three ICON North Sea mussel sites were assessed as green (above BAC, but below EAC) for PAHs, as they were in the QSR2010. Sediment sites common to both studies had the same assessment results for PAHs, with only remote sites at background - here that was at SW Iceland (IS2), whereas in the QSR2010 it was at locations in northern Norway, or the northern North Sea. Assessments of biota PCB concentrations were also similar in this study to in the QSR2010 - with concentrations close to background only in very remote areas (e.g. Iceland here or in northern Norway for the QSR2010). However, ICON sediment PCB assessments generally indicated better status than in the QSR2010. Sediments from the coastal North Sea were mostly red (>EAC) in 2007, but green or blue here, whereas offshore sites were largely green in the QSR2010 and blue here. Slight improvements in the status assessment here compared to in the QSR2010 (e.g. Cd and PCBs in sediments) may reflect the different assessment processes. In the QSR, OSPAR compared the BAC/EAC with the error around the fitted value from the last year of a trend assessment, whereas here we compared either the mean $\pm 95 \%$ confidence interval or the measurement uncertainty with the assessment criteria. Sediment mercury concentrations were above the ERL in most coastal North Sea sediments in both this study and the QSR2010, with biota concentrations very rarely at background in either study. In this study, the biota assessment for $\mathrm{Hg}$ was usually red (above the EQS), whereas in the QSR2010 biota were usually assessed as green as OSPAR used the EC food regulation for the upper transition, rather than the EQS; the food regulation limit was not exceeded in this study.

In summary, the Icelandic sites had relatively low concentrations of organics and most metals, but relatively high concentrations of $\mathrm{Cd}$ and $\mathrm{Cu}$, possibly due to volcanic inputs. The offshore North Sea sites generally had relatively low concentrations of contaminants, although fish in some areas had relatively high liver $\mathrm{Cd}$ concentrations, possibly related to hydrographic conditions. The inshore and estuarine North Sea sites had the highest contaminant concentrations, particularly the Seine (PCBs and PAHs), Forth estuary (PAHs and $\mathrm{Hg}$ ) and Wadden Sea (PCBs/metals). The Baltic Sea site (Mecklenberg Bight) had relatively high concentrations of lead and PAHs in sediments, and of PCBs in flounder (but not in dab) livers. The SE of Spain had relatively high metals concentrations, ascribed to local inputs from mining wastes and natural geology. At many sites, upper-level assessment criteria were exceeded, and at no sites were concentrations of all substances at background. These findings reflect earlier studies and indicate a need to investigate whether adverse biological effects are occurring as a result of simultaneous exposure to multiple contaminants, and a need to produce a holistic assessment of environmental health at these sites, based upon chemical concentrations and concomitant biological responses. These needs were also investigated during the ICON project and are presented in the accompanying papers of this issue (e.g. Burgeot et al., Carney Almroth et al., Hylland et al., Kammann et al., Lang et al., Lyons et al., Martínez-Gómez et al., Vethaak et al., all this issue). A full assessment of the ICON data, including effects, can be found elsewhere in this issue (Hylland et al., this issue).

\section{Conclusions}


This study shows that exposure of marine organisms to so-called legacy environmental contaminants continues to be a pan-European issue, particularly for industrialised estuaries and nearby coastal waters. The study further highlights the benefits of the traffic-light approach to assessing the environmental status of contaminants as it readily summarises the significant findings, enabling communication with policymakers, stakeholders and the general public. The wide geographic scale of this study also indicates the suitability of the approach for conducting the (sub-) regional sea scale assessments that are required under the Marine Strategy Framework Directive. There remains a need to know whether multiple contaminant exposures compromise environmental health and this requires an integration of knowledge on both contaminant concentrations and their biological impacts.

637

638

639

640

641

642

643

644

645

646

647

648

649

650

651

652

653

654

655

656

657

658

659

660

661

662

663

664

665

666

667

668

669

670

671

672

673

674

\section{Acknowledgements}

The authors thank the crews of the research vessels and the staff at the participating institutions who collected samples, the input of Marine Scotland staff who undertook sample analyses, and the participation and support of the ICON Steering Group. Finally, the authors also thank Brett Lyons and Jean François Chiffoleau for provision of UK and French national monitoring data, respectively. Chemical analyses at Marine Scotland were undertaken with the support of the Scottish Government as part of Service Level Agreement AE03o.

\section{References}

Angelidis, M.O., Radakovitch, O., Veron, A., Aloupi, M., Heussner, S., Price B. (2011). Anthropogenic metal contamination and sapropel imprints in deep Mediterranean sediments. Mar. Pollut. Bull., 62, 1041-1052.

Abarnou, A., Avoine, J., Dupont, J.P., Lafite, R., and Simon, S. 1987. Role of suspended sediments on the distribution of PCB in the Seine Estuary (France). Cont. Shelf Res., 7, 1345-1350.

Bakker, J., Lüerßen, G., Marencic, H., Jung, K. 2009. Hazardous Substances. Thematic Report No. 5.1. In: Marencic, H. and Vlas, J. de (Eds.), 2009. Quality Status Report 2009. Wadden Sea Ecosystem No. 25. Common Wadden Sea Secretariat, Trilateral Monitoring and Assessment Group, Wilhelmshaven, Germany.

Baxter, J.M., Boyd, I.L., Cox, M., Donald, A.E., Malcolm, S.J., Miles, H., Miller, B., Moffat, C.F., (Editors), 2011. Scotland's Marine Atlas: Information for the national marine plan. Marine Scotland, Edinburgh. pp. 191. Available from: http://www.gov.scot/Publications/2011/03/16182005/0 [last accessed 29/01/2016]

Benedicto J., Martínez-Gómez C. and Campillo J. 2005. Induction of metallothioneins in Mullus barbatus as specific biomarker of metal contamination: A field study in the western Mediterranean. Cienc. Mar., 31, 264-274.

Benedicto, J., Martínez-Gómez, C., Guerrero, J., Jornet, J., Rodríguez, C. 2008. Metal contamination in Portmán Bay (Murcia, SE Spain) 15 years after the cessation of mining activities. Cienc. Mar., 34, 389-398. 
Benedicto, J., Andral, B., Martínez-Gómez C., Guitart, C., Deudero, S., Cento, A., Scarpato, A., Caixach, J., Benbrahim, S., Chouba, L., Boulahdidi, M., Galgani, F. 2011. A large scale survey of trace metal levels in coastal waters of the Western Monit., 13, 1495-1505.

Benedicto, J., Campillo, J.A., Fernández, B., Martínez-Gómez, C., León, V.M. 2012. Estrategias Marinas: Evaluación inicial, buen estado ambiental y objetivos ambientales. Demarcación marina Levantino-Balear. Parte IV. Descriptores del buen estado ambiental. Descriptor 8. Contaminantes y sus efectos. Evaluación inicial y buen estado ambiental. Ministerio de Agricultura, Alimentación y Medio Ambiente, Madrid, Spain. 110pp. NIPO: 280-12-175-8. Available from: http://www.magrama.gob.es/es/costas/temas/proteccion-medio-marino/IV D8 Levantino-Balear tcm7-207261.pdf (last accessed 01/10/2015)

Bernhard, M. 1988. Mercury in the Mediterranean. UNEP Regional Seas Reports and Studies no. 98. United Nations Environment Programme, 146pp.

Bodin, N., Le Loc'h, F., Caisey, X., Le Guellec, A.M., Abarnou, A., Loizeau, V., and Latrouite, D. 2008. Congener-specific accumulation and trophic transfer of polychlorinated biphenyls in spider crab food webs revealed by stable isotope analysis. Environ. Pollut., 151, 252-261.

Burgeot, T., Akcha, F., Menard, D., Robinson, C.D., Loizeau, V., Brach-Papa, C., Martínez-Gómez, C., Le Goff, J., Budzinski, H., Le Menach, K., Cachot, J., Minier, C., Breog, K., and Hylland, K. 2015. Integrated monitoring of chemicals and their effects on four sentinel species, Limanda limanda, Platichthys flesus, Nucella lapillus and Mytilus sp, in Seine Bay: a key step towards applying biological effects to monitoring. Mar. Environ. Res., this issue.

Cachot, J., Geffard, O., Augagneur, S., Lacroix, S., Le Menach, K., Peluhet, L., Couteau, J., Denier, X., Devier, M.H., Pottier, D., and Budzinski, H. 2006. Evidence of genotoxicity related to high PAH content of sediments in the upper part of the Seine estuary (Normandy, France). Aquat. Toxicol., 79, 257-267.

Carney Almroth, B., Hultman, M., Wassmur, B., Sturve, J., 2015. Determining oxidative stress and EROD activity in dab (Limanda limanda) in the North Sea, from the Baltic to Iceland. Mar., Environ., Res., this issue.

Cesar, A., Marín, A., Marín-Guirao, L., and Vita, R. 2004. Amphipod and sea-urchin tests to assess the toxicity of Mediterranean sediments: the case of Portmán Bay. Cienc. Mar., 68, 205-213.

Chiffoleau J.J.-F., Auger D., Chartier, E., Michel, P., Truquet, I., Ficht A., Gonzalez J.L., Romania L.A., 2001. Spatiotemporal changes in cadmium contamination in the Seine Estuary (France). Estuaries, 24, 1029-1040.

Cossa D., and Coquery, M. 2005. The Mediterranean Mercury Anomaly, a Geochemical or a Biologocal Issue. In: Saliot, A. (Ed.), The Handbook of 
Environmental Chemistry, vol. 5, part K: The Mediterranean Sea. Springer-Verlag,

Cresson, P., Fabri, M.C., Bouchoucha, M., Brach Papa, C., Chavanon, f., Jadoud, A.,Knoery, J., Miralles, F., Cossa, D. 2014. Mercury in organisms from the Northwestern Mediterranean slope: Importance of food sources. Sci. Tot. Environ., 497-498, 229-238.

Davies, I.M. and Vethaak, A.D. (ed.s) 2012. Integrated marine environmental monitoring of chemicals and their effects. ICES Cooperative Research Report no. 315. International Council for the Exploration of the Sea, Copenhagen, Denmark. 277pp.

Available

from: http://www.ices.dk/sites/pub/Publication\%20Reports/Cooperative\%20Research\%20 Report\%20(CRR)/crr315/CRR315 Integrated\%20Monitoring final.pdf (last accessed 01/04/2016)

EC 2005. Environmental Quality Standards (EQS) Substance Data Sheet. Priority Substance No. 21 Mercury and its Compounds. Common Implementation Strategy for the Water Framework Directive (2000/60/EC), available from https://circabc. europa.eu/sd/a/ff8e163c-71f6-4fc0-98ef-875a20add4c8/21 Mercury EQSdatasheet 150105.pdf (last accessed 09/11/2015)

EC 2006. Commission Regulation (EC) No 1881/2006 of 19 December 2006 setting maximum levels for certain contaminants in foodstuffs. Official Journal of the

749 European Union, L364. Consolidated version available from: http://eur750 lex.europa.eu/legal-content/EN/TXT/PDF/?uri=CELEX:02006R1881-20140901\&from

EC 2008a. Directive 2008/56/EC of 17 June 2008 establishing a framework for community action in the field of marine environmental policy (Marine Strategy Framework Directive). Official Journal of the European Union, L164, 19-40.

EC 2008b. Commission Regulation (EC) No 629/2008 of 2 July 2008 amending Regulation (EC) No 1881/2006 setting maximum levels for certain contaminants in foodstuffs. Official Journal of the European Union, L173, 6-9

EC 2008c. Directive 2008/105/EC of the European Parliament and of the Council of 16 December 2008 on Environmental Quality Standards in the Field of Water Policy. Official Journal of the European Union, L348, 84-97.

EC 2011. The Technical Guidance for Deriving Environmental Quality Standards (TGD-EQS). Guidance Document no. 27 of the Common Implementation Strategy for the Water Framework Directive (2000/60/EC). Technical Report - 2011 - 055.

EU 2014. Guidance Document on Biota Monitoring (the Implementation of EQS biota) $_{\text {) }}$ under the Water Framework Directive. Guidance Document no. 32 of the Common Implementation Strategy for the Water Framework Directive (2000/60/EC). Technical Report - 2014-085. 
Fernández, B., Campillo, J.A., Martínez-Gómez, C., Benedicto, J. 2010. Antioxidant responses in gills of mussel (Mytilus galloprovincialis) as biomarkers of environmental stress along the Spanish Mediterranean coast. Aquatic Toxicol., 99, 186-197.

Fernández, B., Campillo, J.A., Martínez-Gómez, C., Benedicto, J. 2011. Micronuclei and other nuclear abnormalities in mussels (Mytilus galloprovincialis) as biomarkers of cyto-genotoxic pollution in Mediterranean waters. Environ. Mol. Mut., 52, 479491.

HELCOM. 2010. Hazardous Substances in the Baltic Sea - An integrated thematic assessment of hazardous substances in the Baltic Sea. Balt. Sea Environ. Proc. No. 120B.

Hylland, K., Burgeot, T., Martínez-Gómez, C., Lang, T., Robinson, C.D., Svarvarsson, J., Thain, J.E., Vethaak, A.D., and Gubbins, M.J. In press. How can we quantify impacts of contaminants in marine ecosystems? The ICON project. Mar. Environ. Res., this issue, doi:10.1016/j.marenvres.2015.11.006

Kammann, U., Akcha, F., Budzinski, H., Burgeot, T., Gubbins, M.J., Lang, T., Le Menach, K., Vethaak, A.D. and Hylland, K. PAH metabolites in fish bile: from the Seine estuary to Iceland. Mar. Env. Res., this issue, submitted

Kinacigil, H.T., Ilkyaz, A.T., Akyol, O., Matin, G., Çira, E., Ayaz, A. 2001. Growth parameters of Red Mullet (Mullus barbatus L., 1758) and seasonal cod-end selectivity of traditional bottom trawl nets in Izmir Bay (Aegean Sea). Acta Adriatica, 42, 113-123.

Lang, T., Feist, S.W. , Stentiford, G.D., Bignell, J.P., Vethaak, A.D. and Wosniok, W. (2016). Diseases of dab (Limanda limanda): Analysis and assessment of data on externally visible diseases, macroscopic liver neoplasms and liver histopathology in the North Sea, Baltic Sea and off Iceland. Mar. Environ. Res., this issue, http://dx.doi.org/10.1016/j.marenvres.2015.12.009

Lyons, B.P., Bignell, J.P., Stentiford, G.D., Bolam, T.P.C, Rumney, H., Bersuder, P., Barber, J.L., Askem, C.E., Nicolaus, M.E.E. and Maes, T. 2015. Determining Good Environmental Status under the Marine Strategy Framework Directive: Case study for descriptor 8 (chemical contaminants), Mar. Env. Res., this issue.http://dx.doi.org/10.1016/j.marenvres.2015.12.010

Martínez-Frias, J., Navarro, A., Lunar, R. and Garcia-Guinea, J. 1998. Mercury pollution in a large marine basin: A natural venting system in the south-west Mediterranean margin. Nature \& Resources, 34, 9-15.

Martínez-Gómez, C., Benedicto, J., Campillo, J.A., Moore, M.N. 2008. Application and evaluation of the neutral red retention (NRR) assay for lysosomal stability in mussel populations along the Iberian Mediterranean coast. J. Environ. Monit., 10, 490-499. 
Martínez-Gómez, C., Fernández, B., Benedicto, J.M., Valdés, J., Campillo, J.A., 824 León, V.M., Vethaak, A.D. 2012. Health status of red mullets from polluted areas of the Spanish Mediterranean coast, with special reference to Portmán (SE Spain).

Martínez-Gómez C., Burgeot T., Robinson, C.D., Gubbins, M.J., Halldorsson, H.P., Albentosa, M., Bignell J.P., Hylland, K. and Vethaak A.D. In press. Lysosomal membrane stability and Stress on Stress in mussels as common pan-European contaminant-related biomarkers. General stress biomarkers in mussels for wide regional biomonitoring programmes in Europe: the ICON experience. Mar. Environ. Res., this issue. doi:10.1016/j.marenvres.2015.10.012.

Martínez-Gómez, C., Fernández, B., Robinson, C.D., Campillo, J., León, V.M., Benedicto, J., Hylland, K., Vethaak, A.D. Assessing the good environmental status (GES) of the Cartagena coastal zone (W Mediterranean) using an integrated framework of chemical and biological effect data: a practical case study. Mar. Env. Res., this issue, submitted

NOAA, 1999. Sediment Quality Guidelines developed for the National Status and Trends Program. United States National Oceanic and Atmospheric Administration (NOAA). Available from: http://ccma.nos.noaa.gov/publications/sqg.pdf (last accessed 23.04.2015).

Orlich, S. 2000. Kruskal-Wallis Multiple Comparisons with a MINITAB Macro Dunn's Test. Minitab Inc., PA, USA. 13pp.

OSPAR, 1999. JAMP Guidelines for Monitoring Contaminants in Biota. OSPAR agreement 1999-2, revised 2012. OSPAR Commission, London. 122pp.

OSPAR, 2008. CEMP Assessment Manual. Co-ordinated Environmental Monitoring Programme Assessment Manual for contaminants in sediment and biota. ISBN 9781-906840-20-4. OSPAR Commission, London. 39pp.

OSPAR, 2009. Agreement on CEMP Assessment Criteria for the QSR 2010. OSPAR Agreement 2009-02e. OSPAR Commission, London. 7pp.

OSPAR, 2010a. OSPAR Coordinated Environmental Monitoring Programme (CEMP), OSPAR Agreement 2010-1. OSPAR Commission, London. 29pp.

OSPAR, 2010b. Quality Status Report 2010. OSPAR Commission, London. 176pp. Available from: http://qsr2010.ospar.org/en/downloads.html Last accessed 01/04/2016.

Pies, C., Hoffmann, B., Petrowsky, J., Yang, Y., Ternes, T.A., and Hofmann, T. 2008. Characterization and source identification of polycyclic aromatic hydrocarbons (PAHs) in river bank soils. Chemosphere, 72, 1594-1601.

Rocher, B., Le Goff, J., Peluhet, L., Briand, M., Manduzio, H., Gallois, J,, Devier, M.H., Geffard, O., Gricourt, L., Augagneur, S., Budzinski, H., Pottier, D., André, V., Lebailly, P., and Cachot, J. 2006. Genotoxicant accumulation and cellular defence 
activation in bivalves chronically exposed to waterborne contaminants from the Seine River. Aquat. Toxicol., 79, 65-77.

Salomons, W., Bayne, B.L., Duursma, E.K., Förstner, U. (Eds.). 1988. Pollution of the North Sea: An Assessment. Springer-Verlag, Berlin, Heidelberg. 687pp. ISBN 978-3-642-73711-4

Schwarzbauer, J., Littke, R., and Weigelt, V. 2000. Identification of specific organic contaminants for estimating the contribution of the Elbe river to the pollution of the German Bight. Org. Geochem., 31, 1713-1731.

Skarphedinsdottir, H., Gunnarsson, K., Gudmundsson, G.A., and Nfon, E. 2010. Bioaccumulation and biomagnification of organochlorines in a marine food web at a pristine site in Iceland. Arch. Environ. Contam. Toxicol., 58, 800-809.

Smout, T.C. and Stewart, M. 2012. The Firth of Forth: An Environmental History. Birlinn Ltd., Edinburgh. 240pp. ISBN-10: 178027064X. ISBN-13: 978-1780270647

Sturludottir, E., Gunnlaugsdottir, H., Jorundsdottir, H.O., Magnusdottir, E.V., Olafsdottir, K., and Stefansson, G. 2014. Temporal trends of contaminants in cod from Icelandic waters. Sci. Tot. Environ., 476-477, 181-188.

Tobiszewski, M. and Namieśnik, J. 2012. PAH diagnostic ratios for the identification of pollution emission sources. Environ. Pollut., 162, 110-119.

Umlauf, G., Stachel, B., Mariani, G., Götz, R. 2011. Dioxins and PCBs in solid matter from the River Elbe, its tributaries and the North Sea (longitudinal profile, 2008). Scientific and Technical Research Reports, European Union, Luxembourg. 120pp. ISBN 978-92-79-19761-1. ISSN 1018-5593 (print), 1831-9424 (online). doi: $10.2788 / 72323$.

UNEP/FAO/IOC/IAEA. 1993. Guidelines for monitoring chemical contaminants in the sea using marine organisms. RSRM $6 \mathrm{~F}(\mathrm{E})$. Reference Methods for Marine Pollution Studies No. 6., United Nations Environment Programme. 28pp.

UNEP/MAP. 2011. Development of assessment criteria for hazardous substances in the Mediterranean. United Nations Environment Programme, Mediterranean Action Plan, UNEP(DEPI)/MED WG. 365/Inf.8. 41pp. Available from: http://195.97.36.231/dbases/MAPmeetingDocs/11WG365 Inf8 Eng.pdf (last accessed 01/10/2015).

Vethaak, A.D., Davies, I.M., Thain, J.E., Gubbins, M.J., Martínez-Gómez, C., Robinson, C.D., Moffat, C.F., Burgeot, T., Maes, T., Wosniok, W., Giltrap, M., Lang, T., and Hylland, K. In press. Integrated indicator framework and methodology for monitoring and assessment of hazardous substances and their effects in the marine environment. Mar. Environ. Res., this issue. http://dx.doi.org/10.1016/j.marenvres.2015.09.010

Webster, L., Russell, M., Phillips, L. A., Packer, G., Scurfield, J.A., Dalgarno, E. J. and Moffat, C. F. (2009) An assessment of persistent organic pollutants (POPs) in 
923 wild and rope grown blue mussels (Mytilus edulis) from Scottish coastal waters. J. 924 Environ. Monit., 11, 1169 - 1184.

925

926 Webster, L., Russell, M. Walsham, P. Phillips, L.A. Hussy, I. Packer, G. Dalgarno E. 927 J. and Moffat, C. F., 2011. An assessment of persistent organic pollutants in Scottish 928 coastal and offshore marine environments. J. Environ. Monit, 13, 1288-1307.

929

930 Yeats, P.A. 1988. The distribution of trace metals in ocean waters. Sci. Total 931 Environ., 72, 131-149

932

933 Yunker, M.B., Macdonald, R.W., Vingarzan, R., Mitchell, R.H., Goyette, D., 934 Sylvestre, S. 2002. PAHs in the Fraser River basin: a critical appraisal of PAH 935 ratios as indicators of PAH source and composition. Organic Geochemistry, 33, 489936515. 
7. Supplementary Information

941

942

943

944

945

946

947

948

949

950

951

952

953

954

955

956

957

958

959

960

961

962

963

964

965

966

967

968

969

970

971

972
Figure S1: Sediment Cd concentrations ( $\mathrm{mg} / \mathrm{kg}$ dry weight, normalised to $5 \%$ aluminium).

Figure S2: Sediment $\mathrm{Pb}$ concentrations (mg/kg dry weight), normalised to $5 \%$ aluminium.

Figure S3: Sediment $\mathrm{Hg}$ concentrations ( $\mu \mathrm{g} / \mathrm{kg}$ dry weight, normalised to $5 \%$ aluminium).

Figure S4: Concentrations of trace metals ( $\mathrm{mg} / \mathrm{kg}$ wet weight) in fish liver

Figure S5: Principle Components Analysis score plot of trace metal concentrations in fish liver

Figure S6: Principle Components Analysis score plot of trace metal concentrations in mussels

Figure S7: Sediment PCB concentrations (sum of CBs 28, 52, 101, 118, 153, $180 ; \mu \mathrm{g} / \mathrm{kg}$ dry weight, normalised to $2.5 \%$ total organic carbon).

Figure S8: Principle Components Analysis score plot for the composition of Polycyclic Aromatic Hydrocarbons (including naphthalene) in sediments

Figure S9: Principle Components Analysis score plot for the composition of Polycyclic Aromatic Hydrocarbons (excluding naphthalene) in sediments

Table S1: Sediment contaminant concentrations and physicochemical characteristics.

Table S2: Sediment contaminant concentrations normalised to $5 \% \mathrm{Al}$ (metals) or $2.5 \%$ TOC (organics; $\mu \mathrm{g} / \mathrm{kg}$ d.w.).

Table S3: Sediment trace metal concentrations ( $\mathrm{mg} / \mathrm{kg}$ dry $\mathrm{wt}$ ), normalised to $100 \%$ fine grained $(<63 \mu \mathrm{m})$ material.

Table S4: Contaminant concentrations ( $\mu \mathrm{g} / \mathrm{kg}$ wet weight) in mussels

Table S5: Fish age and concentrations ( $\mu \mathrm{g} / \mathrm{kg}$ wet weight) of contaminants in (a) fish muscle and (b) fish liver 
973 Figure 1: Sampling locations for sediment and mussels (A), or fish (B). For 974 explanation of site codes, see Table 1.

975

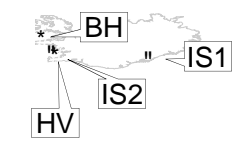

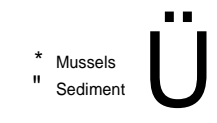

$\underset{02505000 \quad r .000}{\longrightarrow K m}$
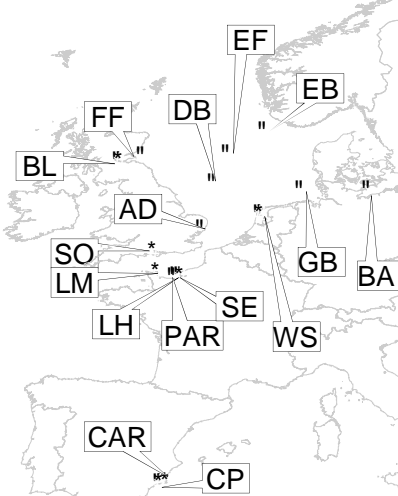

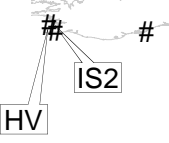

\# Dab, Haddock

$\wedge$ Fab
\# Flounder, Dab
! Red mullet

$\stackrel{250}{500} \mathrm{Km}$ 
979 Figure 2: Assessment of data using the "traffic light" system (amended from 980 OSPAR, 2008 and UNEP/MAP, 2011). A = concentrations below the lower transition 981 point $\left(T_{0}\right)$ and at background; $B$ \& $C=$ above background, but not of environmental 982 concern; $D \& E=$ above the upper transition level $\left(T_{1}\right)$ and adverse impacts possible. $E Q S=E U$ Environmental Quality Standard; $E A C=$ Environmental Assessment Criteria; ERL = US Effects Range Low; MPC = Maximum Permitted Concentration under $\mathrm{EC}$ food Regulations; $\mathrm{BAC}=$ Background Assessment Concentration. In OSPAR (2008) concentrations between the BAC and the food regulation limit were coloured amber, rather than green.

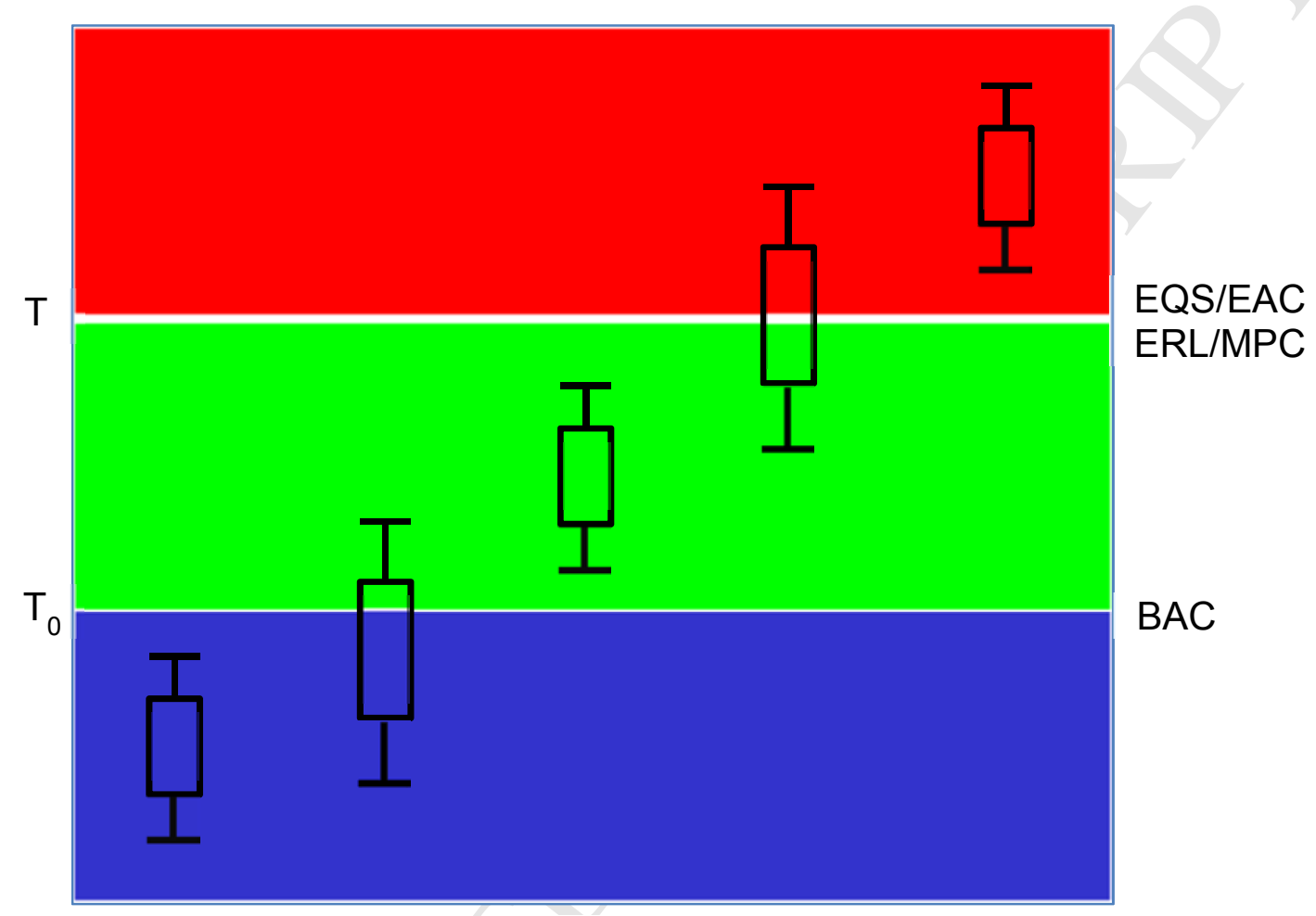
A
B
C
D
$E$ 
991 Figure 3: Principle Components plot of sediment trace metals concentrations 992 (normalised to $5 \%$ aluminium). PC1 = high metal concentrations $(67 \%$ of total 993 variation); $\mathrm{PC2}=$ very high $\mathrm{Cu}$ and higher $\mathrm{Cd}$ concentrations (17\% of total variation). 994 Site code abbreviations defined in Table 1.

995

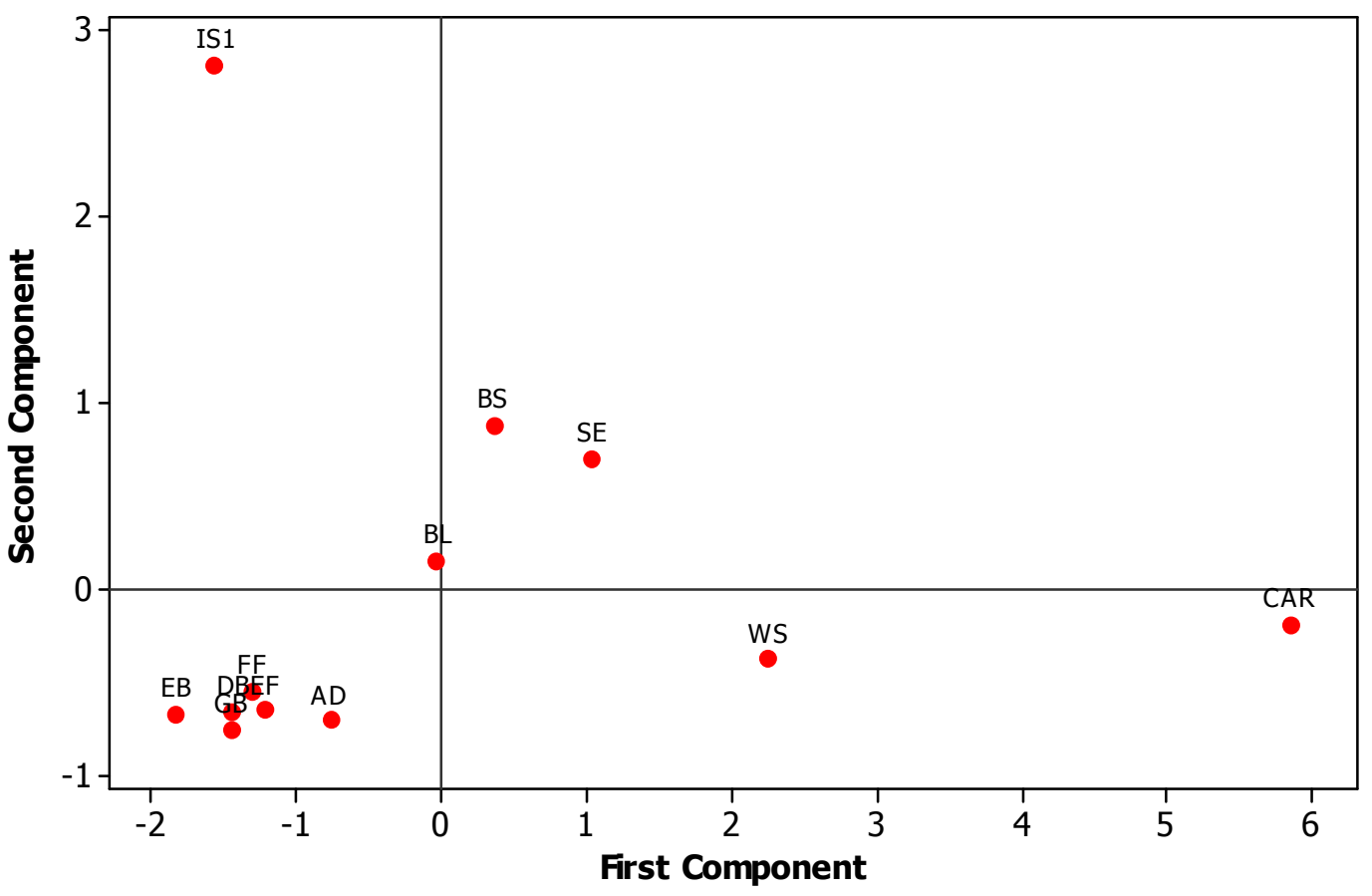


1001 Figure 4: Sediment PAH concentrations (sum of naphthalene, phenanthrene, 1002 anthracene, fluoranthene, pyrene, benz[a]anthracene, chrysene/triphenylene, 1003 benzofluoranthenes, benzo[a]pyrene, indenopyrene, benzoperylene; $\mu \mathrm{g} / \mathrm{kg}$ dry 1004 weight normalised to $2.5 \%$ total organic carbon). Colours indicate the status 1005 assessment, which is based upon the number of individual compounds exceeding 1006 their respective assessment criteria, rather than total $\mathrm{PAH}$ concentration; blue = 1007 concentrations at background, green = concentrations of 2 or more individual PAHs 1008 elevated (>BAC), but not of significant environmental concern, red = concentrations 1009 elevated for 2 or more individual PAHs (>ERL) and could cause adverse effects.

1010

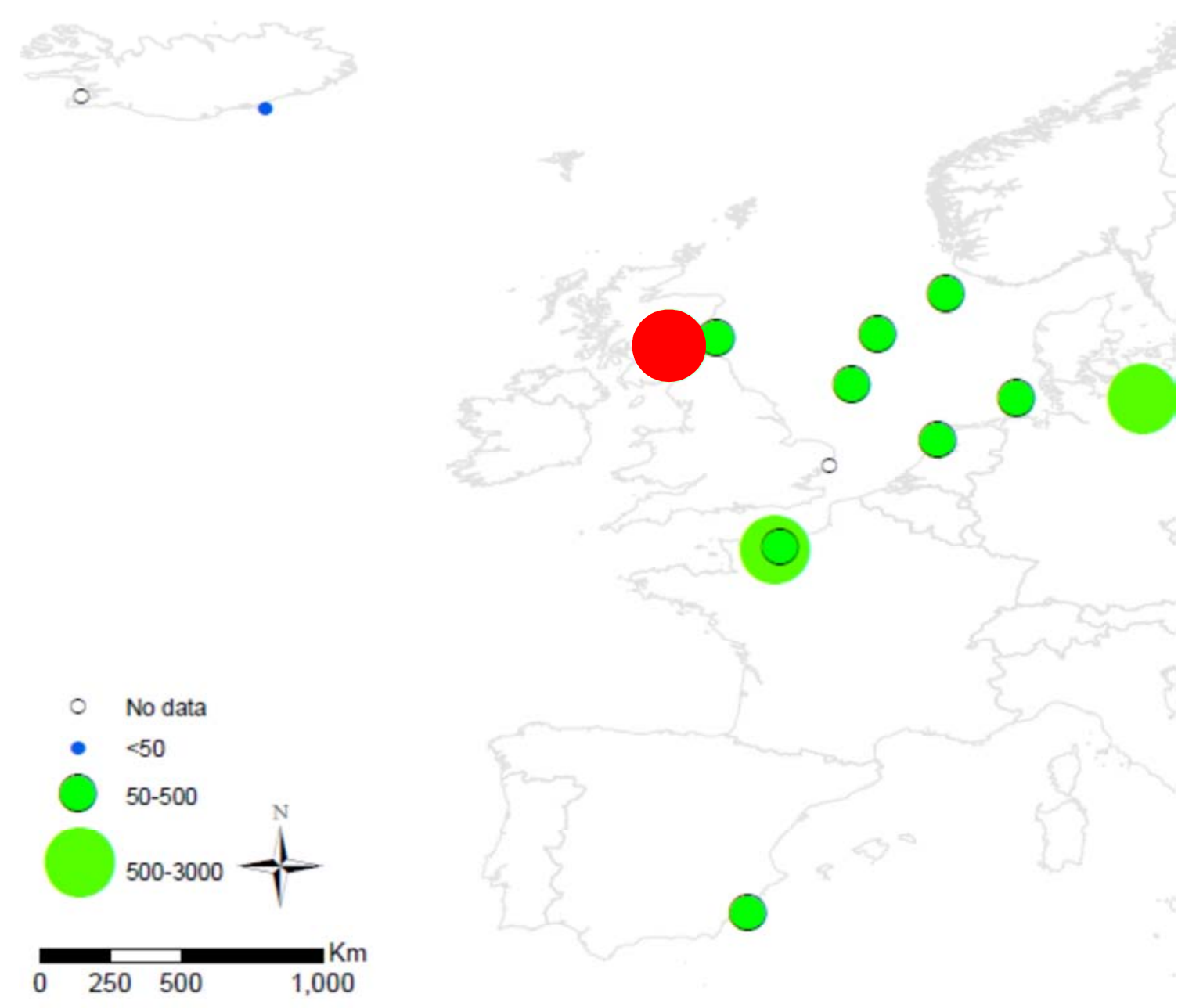


1013 Figure 5: Number (a) and proportion (b) of results in each assessment category. 1014 Blue $=$ concentrations close-to- background $(<\mathrm{T} 0)$, green $=$ concentrations elevated, 1015 but not of significant environmental concern, red = concentrations elevated and could 1016 cause adverse effects (>T1); grey = no data.

1017

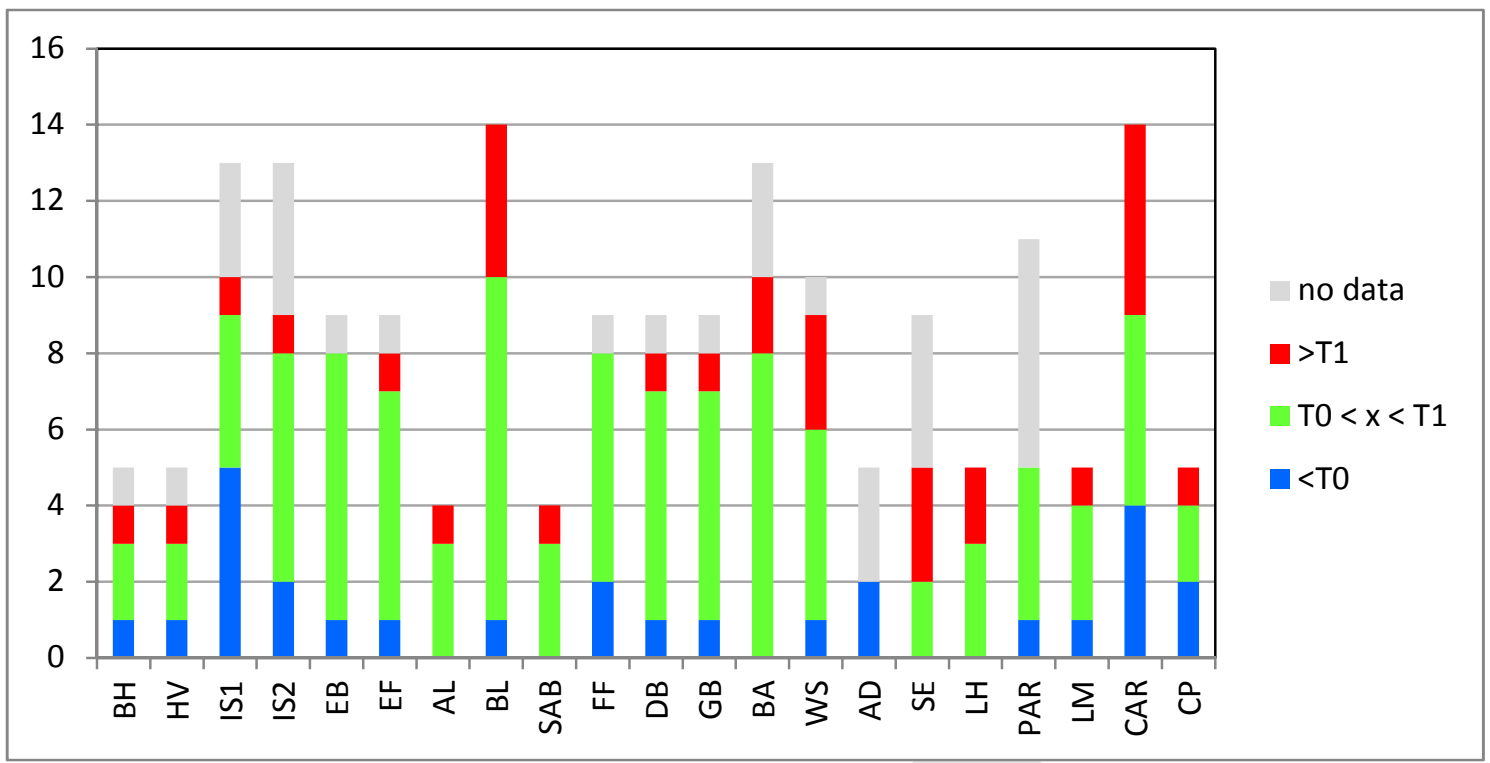

1018

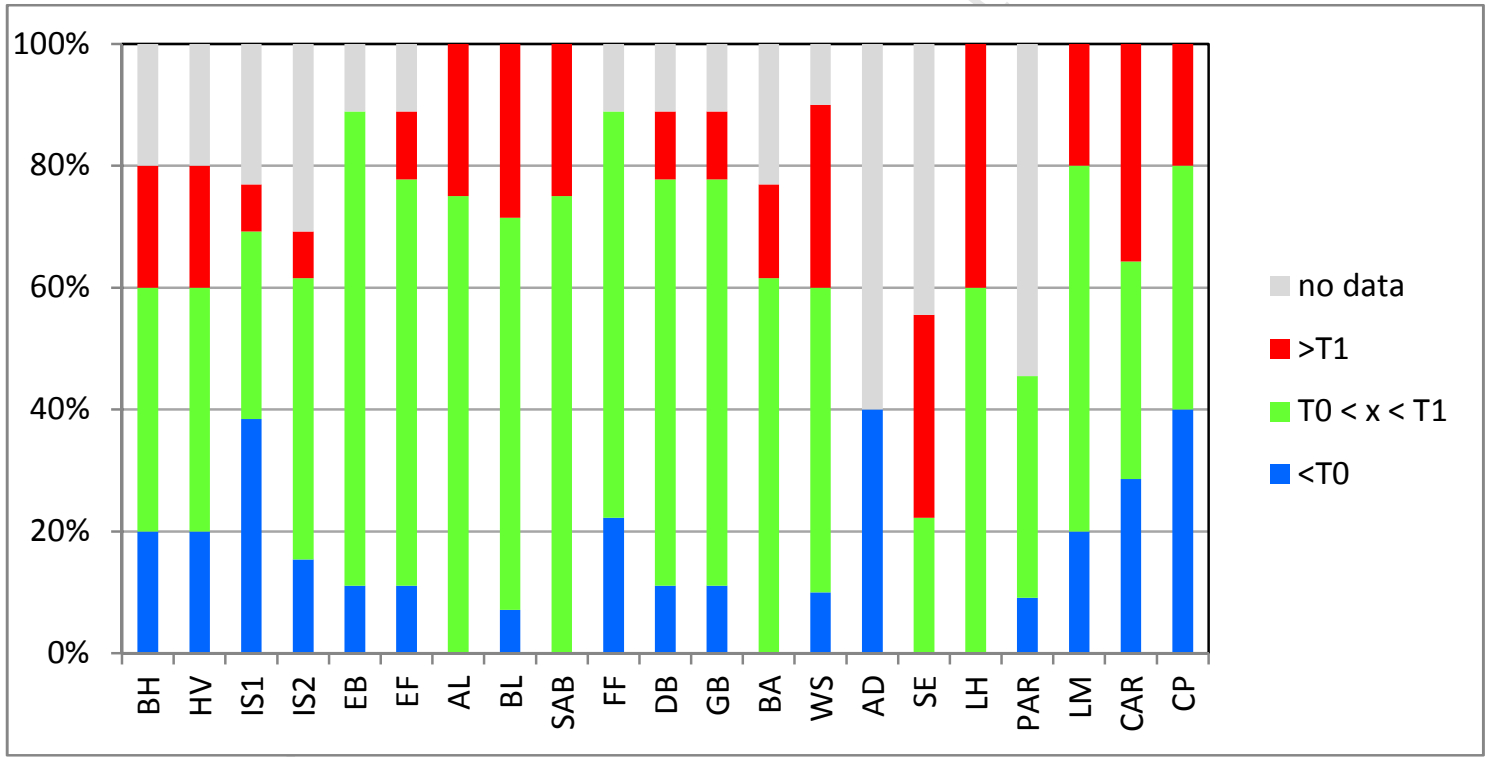


Table 1: Sampling site information.

1022

\begin{tabular}{llllrrl} 
Region & Site name & Site code & Site type & Latitude & Longitude & Samples collected \\
\hline Iceland & Bjarnarhöfn & BH & Coastal & 65.000 & -22.970 & Mussels \\
Iceland & Hvassahraun & HV & Coastal & 64.023 & -22.146 & Mussels \\
Iceland & SE Iceland & IS1 & Offshore & 63.767 & -16.404 & Dab, haddock, sediment \\
Iceland & SW Iceland & IS2 & Offshore & 64.146 & -22.280 & Dab, haddock, sediment \\
North Sea & Egersund bank & EB & Offshore & 57.708 & 5.295 & Haddock, sediment \\
North Sea & Ekofisk & EF & Offshore & 56.402 & 3.095 Dab, haddock, sediment \\
North Sea & Forth estuary - Alloa & AL & Estuary & 56.110 & -3.810 & Flounder \\
North Sea & Forth estuary - Blackness & BL & Estuary & 56.014 & -3.480 & Flounder, mussels, sediment, \\
North Sea & Firth of Forth - St Andrews Bay & SAB & Coastal & 56.407 & -2.739 Flounder \\
North Sea & Firth of Forth - offshore & FF & Offshore & 56.300 & -2.034 Dab, haddock, sediment \\
North Sea & Dogger Bank & DB & Offshore & 54.748 & 2.271 Dab, sediment \\
North Sea & German Bight & GB & Offshore & 54.338 & 7.537 & Dab, sediment \\
Baltic Sea & Mecklenberg Bight, Baltic Sea & BA & Coastal & 54.333 & 11.600 Flounder, dab, sediment \\
North Sea & Wadden Sea & WS & Coastal & 52.965 & 5.017 & Mussels, sediment \\
North Sea & Alde & AD & Estuary & 52.096 & 1.561 & Sediment \\
English Channel & Seine estuary & SE & Estuary & 49.431 & 0.003 Dab, sediment \\
English Channel & Le Havre & LH & Estuary & 49.423 & 0.209 & Mussels \\
English Channel & Parfond (Seine Bay) & PAR & Coastal & 49.385 & -0.154 & Dab, flounder, sediment \\
English Channel & Le Moulard & LM & Coastal & 49.653 & -1.238 & Mussels \\
Mediterranean Sea & Cartagena & CAR & Coastal & 37.562 & -1.030 & Red mullet, mussels, sediment \\
Mediterranean Sea & Marine Reserve of Cape Palos & CP & Coastal & 37.653 & -0.653 Mussels
\end{tabular}


1025 Table 2: Criteria used in assessing ICON contaminant data. Values are dry weight for sediments (with OSPAR BACs normalised 1026 to $5 \% \mathrm{Al}$ or $2.5 \% \mathrm{TOC}^{2}$ ), wet weight for biota (BACs/EACs converted from dry weight using a factor of 5 ). BAC = Background 1027 Assessment Concentration; EAC = Environmental Assessment Criteria; ERL = Effects Range Low; EQS = Environmental Quality 1028 Standard; MPC = Maximum Permitted Concentration. BACs were used for the blue/green assessment transition ( $\mathrm{T}_{0}$ ); EQSs, 1029 EACs, ERLs or MPCs were used for the green/red assessment transition $\left(\mathrm{T}_{1}\right)$.

1030

\begin{tabular}{|c|c|c|c|c|c|c|c|c|c|c|c|c|c|c|}
\hline \multirow[b]{2}{*}{ Metals (mg/kg) } & \multicolumn{4}{|c|}{ Sediment } & \multicolumn{4}{|c|}{ Mussels } & \multicolumn{2}{|c|}{ Fish liver } & \multicolumn{4}{|c|}{ Fish muscle } \\
\hline & $\begin{array}{r}\text { BAC } \\
\text { Spain }^{1}\end{array}$ & & $\mathrm{BAC}^{2}$ & $E R L^{3}$ & $\begin{array}{r}\text { BAC } \\
\text { Spain }^{4}\end{array}$ & $\mathrm{BAC}^{2}$ & $\mathrm{EQS}^{5}$ & $\mathrm{MPC}^{6}$ & $\mathrm{BAC}^{2}$ & $\mathrm{MPC}^{6}$ & $\begin{array}{r}\text { BAC } \\
\text { Spain }^{4}\end{array}$ & $\mathrm{BAC}^{2}$ & $\mathrm{EQS}^{5}$ & $\mathrm{MPC}^{6}$ \\
\hline $\mathrm{Cd}$ & 0.15 & & $0.31^{*}$ & 1.2 & 0.22 & 0.19 & & 1 & 0.026 & 1 & 0.002 & 0.026 & & 0.05 \\
\hline $\mathrm{Hg}$ & 0.045 & & $0.07^{*}$ & 0.15 & 0.04 & 0.018 & 0.02 & & & & 0.12 & 0.035 & 0.02 & \\
\hline $\mathrm{Pb}$ & 30 & & $38^{*}$ & 46.7 & 0.76 & 0.26 & & 1.5 & 0.026 & 1.5 & 0.11 & 0.026 & & 0.3 \\
\hline PAHs $(\mu \mathrm{g} / \mathrm{kg})$ & $\begin{array}{r}\text { BAC } \\
\text { Spain }^{2} \\
\end{array}$ & & $\mathrm{BAC}^{2}$ & $\mathrm{ERL}^{3}$ & $\begin{array}{r}\text { BAC } \\
\text { Spain }^{4}\end{array}$ & $\mathrm{BAC}^{2}$ & $\mathrm{EAC}^{2}$ & $\mathrm{EQS}^{5}$ & & & & & & \\
\hline Naphthalene & & & 8 & 160 & & & 68 & & & & & & & \\
\hline Phenanthrene & 7.3 & & $32^{\star *}$ & 240 & 4.86 & 2.2 & 340 & & & & & & & \\
\hline Anthracene & 1.8 & & $5^{\star *}$ & 85 & 0.82 & & 58 & & & & & & & \\
\hline Fluoranthene & 14.4 & & $39^{* *}$ & 600 & 1.36 & 2.44 & & 30 & & & & & & \\
\hline Pyrene & 11.3 & & $24^{* *}$ & 665 & 1.22 & 1.8 & 20 & & & & & & & \\
\hline Chrysene & 8 & & $20^{* *}$ & 384 & 0.42 & 1.62 & & & & & & & & \\
\hline Benz[a]anthracene & 7.1 & & $16^{* *}$ & 261 & 0.26 & 0.5 & 16 & & & & & & & \\
\hline Benzo[k]fluoranthene & & & & & 0.36 & & 52 & & & & & & & \\
\hline Benzo[a]pyrene & 8.2 & & $30^{* *}$ & 430 & 0.26 & 0.28 & & 5 & & & & & & \\
\hline Benzo[ $[g, h, i]$ perylene & 6.9 & & $80^{* *}$ & & 0.26 & 0.5 & 22 & & & & & & & \\
\hline Indeno[ $[1,2,3-c, d]$ pyrene & 8.3 & & $103^{* *}$ & & 0.16 & 0.48 & & & & & & & & \\
\hline PCBs $(\mu \mathrm{g} / \mathrm{kg})$ & $\begin{array}{r}\text { BAC } \\
\text { Spain }^{2} \\
\end{array}$ & $\mathrm{ERL}^{3+}$ & $\mathrm{BAC}^{2}$ & $\mathrm{EAC}^{2}$ & $\begin{array}{r}\text { BAC } \\
\text { Spain }^{2} \\
\end{array}$ & $\mathrm{BAC}^{2}$ & $\mathrm{EAC}^{2}$ & & $\mathrm{BAC}^{2}$ & $\mathrm{MPC}^{6}$ & $\begin{array}{r}\text { BAC } \\
\text { Spain }^{2}\end{array}$ & & & $\mathrm{MPC}^{6}$ \\
\hline CB 118 & & & 0.17 & $0.6^{* *}$ & 0.024 & 0.12 & 0.24 & & 0.12 & - & 0.02 & & & - \\
\hline CB 28 & & & 0.22 & $1.7^{\star *}$ & 0.03 & 0.15 & 0.64 & & 0.15 & & 0.02 & & & \\
\hline CB 52 & & & 0.12 & $2.7^{\star \star}$ & 0.03 & 0.15 & 1.08 & & 0.15 & & 0.016 & & & \\
\hline CB 101 & $0.46^{1}$ & $11.5^{1}$ & 0.14 & $3^{* *}$ & 0.028 & 0.14 & 1.2 & & 0.14 & $2000^{\dagger \dagger}$ & 0.016 & & & \\
\hline CB 138 & & & 0.15 & $7.9^{* *}$ & 0.024 & 0.12 & 3.16 & & 0.12 & 200 & 0.018 & & & $75^{\dagger+}$ \\
\hline CB 153 & & & 0.19 & $40^{\star \star}$ & 0.024 & 0.12 & 16 & & 0.12 & & 0.02 & & & \\
\hline $\begin{array}{r}\text { CB } 180 \\
\end{array}$ & 0 & & 0.1 & $12^{* *}$ & 0.024 & 0.12 & 4.8 & & 0.12 & & 0.022 & & & \\
\hline
\end{tabular}


Table 3: Polycyclic aromatic hydrocarbon (PAH) ratios used for source apportionment in this study (reviewed in Tobiszewski and 1034 Namieśnik, 2012).

1035

Table 4: Polycyclic aromatic hydrocarbon $(\mathrm{PAH})$ source diagnostic ratios observed for sediments in this study. ANT = anthracene; PHEN = phenanthrene; FLUT = fluoranthene; PYR = pyrene; IcdP = indeno[1,2,3,c,d]pyrene; BghiP = benzo[g,h, /perylene. $<D L=$ below detection limit; n.d. = no data

\begin{tabular}{|c|c|c|}
\hline Value & Source & Citation \\
\hline$<0.1$ & Petrogenic & Pies et al., 2008 \\
\hline$>0.1$ & Pyrolytic & \\
\hline$<0.4$ & Petrogenic & Yunker et al., 2002 \\
\hline 0.4-0.5 & $\begin{array}{l}\text { Vehicle and crude oil } \\
\text { combustion }\end{array}$ & \\
\hline$>0.5$ & Coal / biomass combustion & \\
\hline$<0.2$ & Petrogenic & Yunker et al., 2002 \\
\hline $0.2-0.5$ & $\begin{array}{l}\text { Vehicle and crude oil } \\
\text { combustion }\end{array}$ & \\
\hline$>0.5$ & Coal / biomass combustion & \\
\hline
\end{tabular}

ANT / (ANT+PHEN)
FLUT / (FLUT+PYR)
IcdP / (IcdP + BghiP)

\section{IS1}

IS2

EB
0.20

EF $\quad B A$

$\begin{array}{rrr}\text { BA } & \text { BL } & \text { FF } \\ 0.18 & 0.27 & 0.49 \\ 0.53 & 0.45 & 0.41 \\ 0.55 & 0.45 & 0.56\end{array}$

0.14

$<\mathrm{DL} \quad$ n.d. 0.58

0.57

$\begin{array}{llll}<\mathrm{DL} & \text { n.d. } & 0.55 & 0.54\end{array}$

$\begin{array}{cr}\text { DB } & \text { GB } \\ <\mathrm{CL} & 0.13 \\ <\mathrm{CL} & 0.55 \\ <\mathrm{DL} & 0.55\end{array}$

$\begin{array}{crr}\text { PAR } & \text { SE } & \text { WS } \\ 0.01 & 0.25 & 0.22 \\ 0.55 & 0.55 & 0.58 \\ \text { n.d. } & 0.54 & 0.53\end{array}$

AD CAR

n.d. $\quad 0.19$ n.d. $\quad 0.57$ n.d. $\quad 0.45$ 